\title{
The Application of Altman Revised Z-Score Four Variables and Ohlson O-Score as A Bankruptcy Prediction Tool in Small and Medium Enterprise Segments in Indonesia
}

\author{
Adhy Pramudita ${ }^{1, *}$ \\ ${ }^{1}$ University of Indonesia \\ ${ }^{*}$ Corresponding author. Email: adhy.pramudito@ gmail.com
}

\begin{abstract}
The small-medium business segment is currently growing in Indonesia, contributing more than one-fifth of Indonesia's Gross Domestic Product, making this segment is very potential to be developed more. Domestic and foreign banks view this small-medium business segment as a promising segment, and the majority of banks in Indonesia compete to distribute business loans to this segment. However, amid promising prospects, this segment also has its own challenges where the ratio of national non-performing loans exceeds the ratio of non-performing loans to all loans disbursed. This study aims to examine the reliability of the Altman Z-Score and Ohlson O-Score methods as predictors of bankruptcy in Small-Medium Enterprise segment companies in Indonesia and its reliability statements in this segment in reflecting the company's real conditions as input data for analysis prediction of corporate bankruptcy. The research data were financial report data from companies that were debtors of the Small-Medium Enterprise segment at Bank Mandiri. The results showed that the Z-Score calculation results were able to predict bankruptcy with an accuracy of $51.8 \%, 37.4 \%, 36.3 \%$, and $11.4 \%$ for one, two, three, and four years before the bankruptcy. Meanwhile, Ohlson O-Score provided better accuracy results of 73.6\%, $43.2 \%$, and $58.5 \%$ for one, two, and three years before the bankruptcy. Based on these results and also interviews with the internal parties of the bank, it may be concluded that the financial statements for Small-Medium Enterprise segment companies, in general, have not been reliable enough to reflect the company's condition in real terms.
\end{abstract}

Keywords: Bankruptcy Prediction, Z-Score, O-Score, Small-Medium Enterprise.

\section{INTRODUCTION}

Indonesia's economic growth is influenced by the role of the business sector in Indonesia. Based on data released by the Ministry of Cooperatives and SMEs in 2013, the number of business operators in Indonesia amounted to $57,900,787$ businesses. The composition is $98.77 \%$ of the micro business sector, $1.22 \%$ of small and medium enterprises, and $0.01 \%$ of a large business. Meanwhile, GDP indicators based on current prices in 2013, micro-businesses contributed $35.81 \%$, small and medium enterprises at $23.27 \%$, and large businesses at $40.92 \%$. From these data, it can be seen that small and medium enterprises are segments that have the potential to be developed. With a quantity of $1.22 \%$ of the total business operators, it contributes $23.27 \%$ of the GDP indicator at current prices [1].

The considerable potential of SME financing for banks, on the other hand, is quite tempting. However, on the other hand, financing for SMEs is considered to have a high risk. The Indonesian Banking Statistics data issued by the Financial Services Authority for September 2018 shows that the percentage of nonperforming loans (NPL) for credit facilities in the SME segment is relatively high at $4.47 \%$. This is far above the percentage of national banking non-performing loans of $2.66 \%$ and almost reaching the Non-Performing Loan maximum limit based on PBI NUMBER 15/2/PBI/2013 concerning Implementation of Status and Follow-Up Monitoring of Conventional Commercial 
Banks, which limits the maximum NPL charges in Indonesia by $5 \%$. Based on the Financial Services Authority data, the percentage of NPLs for the SME segment increased from 2014 to 2017 and decreased slightly in September 2018. Especially in the classification of Regional Development Banks (BPD), the percentage of NPLs is always $9 \%$ above in that period. The high value of this NPL shows that banks in Indonesia have not been able to manage risk management evenly in the distribution of credit facilities.

The high percentage of Non-Performing Loans in banks in Indonesia, especially in the SME financing segment, shows that the ability of banks in Indonesia to conduct credit analysis in order to gain confidence in the feasibility of debtors is still low. The usage of credit scoring in Indonesian banks as one of the bank's tools to gain confidence is considered to be ineffective. This study is expected to be a reference for bank management to evaluate the credit scoring method used and to find out:

- The Altman Z-Score and Ohlson O-Score methods' accuracy as predictors of bankruptcy in SmallMedium Enterprise segment companies in Indonesia.

- The reliability of the company's financial statements in the Small-Medium Enterprise segment reflects the company's real conditions as input data for analyzing its bankruptcy predictions.

\subsection{Small Medium Enterprise (SME) Segment CreditFacilities}

Based on Law No. 20 of 2008, the definition of Small and Medium Enterprise (SMEs) is a company that has assets between Rp50 million to Rp10 billion and annual sales between Rp300 million and Rp50 billion. In the Bank Mandiri Credit Procedure Standard (SPK), which is the object of this study, the Credit Facility for the SME segment is a facility intended for companies with annual sales smaller than Rp50 billion with a facility limit of between Rp200 million to Rp25 billion. Credit facilities provided by the bank may in the form of Working Capital Loans, Investment Loans, and Trade Finance.

\subsection{Credit Scoring and Credit Rating}

Credit Scoring may be defined as a tool used to evaluate the credit risk level associated with prospective debtors [2]. The application of scoring techniques is conducted to assess individual creditworthiness or, in other words, to a company that is a crucial personoriented. Meanwhile, the rating technique may be applied to see a company's feasibility by being oriented towards the company itself.

\subsection{Bankruptcy and Financial Difficulties}

According to the Black Laws Dictionary, the definition of bankruptcy is a condition in which a person (individual or company) is unable to pay the debt properly or is due based on voluntary submission or submitted by another party to the court.

Financial distress may push a person or company to bankruptcy. Financial distress is a condition in which an operating cash flow of a company is not enough to meet the company's current liabilities (such as trade debt or interest costs), and the company is required to take corrective steps [3].

\subsection{Altman Z-Score Model}

Edward Altman composed modeling using financial statement ratios and multiple discriminant analyses to predict bankruptcy in manufacturing companies listed on the Stock Exchange [4]. The modeling conducted by Altman uses five financial ratios for its calculations with (1).

$Z=3,3 X 1+1,2 X 2+1,0 X 3+0,6 X 4+1,4 X 5$

In which:

- $\mathrm{Z}=$ bankruptcy index

- $\mathrm{X} 1=$ Profit before interest and tax (EBIT) / Total Asset

- $\quad \mathrm{X} 2=$ Net Working Capital / Total Assets

- $\mathrm{X} 3=$ Sales $/$ Total Assets

- $\mathrm{X} 4=$ Market value of capital / Book value of debt

- $\mathrm{X} 5=$ Accumulated retained earnings / Total Assets

Table 1 shows the zone of discrimination Z-score.

Table 1. Zone of Discrimination Z Score

\begin{tabular}{|c|l|l|}
\hline & \multicolumn{1}{|c|}{ Z-Score } & \multicolumn{1}{c|}{ EMS Z- Score } \\
\hline Safe Zone & $\mathrm{Z}>2,99$ & $\mathrm{Z}$ ' $>2,6$ \\
\hline GreyZone & $1,81<\mathrm{Z}<2,99$ & $1,25<\mathrm{Z}$ ' $<2,9$ \\
\hline DistressZone & $\mathrm{Z}<1,81$ & $\mathrm{Z}$ ' $<1,25$ \\
\hline
\end{tabular}

In 2005, Altman introduced the Z-Score model with an approach to emerging markets and could be used for manufacturing and non-manufacturing companies. The model is called the Emerging Market System (EMS), the formula can be seen in (2) [5].

$$
Z "=6,56(X 1)+3,26(X 2)+6,72(X 3)+1,05(X 4)+3,25
$$

In which:

- $\mathrm{X} 1=$ working capital/total assets

- $\quad \mathrm{X}_{2}=$ retained earnings/total assets 
- $\mathrm{X} 3=$ operating income/total assets;

- $\mathrm{X} 4=$ book value of equity/total liabilities

Whereas the constant value of 3.25 is the median value of the Z" Score of the US companies. This Z" Score model will become a reference in this study by considering the research object, a trading company that is not listed on the capital market and located in Indonesia, which is an emerging market. The constant value of 3.25 cannot be used because Altman uses these constants to conduct a company calibration assessment on his research, contrary to this study where there is no standardization of company rankings.

\subsection{Ohlson O-Score}

Another model to predict bankruptcy is the Ohlson OScore [6] model. This modeling uses a statistical logistic regression method, which is commonly used to predict an event's probability of occurrence by matching data to the logit curve logistic function.

To predict the probability of the liability of a company. Ohlson uses nine company financial ratios with the following (3) [6].

$$
\begin{aligned}
& \mathrm{O}=-1,32-0,407 \times 1+6,03 \times 2- \\
& 1,43 \times 3+0,0757 \times 4-2,37 \times 5-1,83 \times 6+0,285 \times 7 \\
& -1,72 \times 8-0,521 \times 9
\end{aligned}
$$

In which:

- $\mathrm{O}$ is the bankruptcy probability.

- $\mathrm{X} 1$ is the Log (Total assets / GNP price-level index).

- $\quad \mathrm{X} 2$ is the total liability / total assets.

- $\mathrm{X} 3$ is Net Working Capital / Total assets.

- $\mathrm{X} 4$ is current liability / current assets.

- $\mathrm{X} 5$ is 1 if the total liability > total assets, other than that $=0$.

- $\mathrm{X} 6$ is the net income / total assets.

- $\quad \mathrm{X} 7$ is the funds from operations / total liability.

- $\mathrm{X} 8$ is 1 [1 if the net income is negative for the last 2 years, other than that $=0$ ].

- $\quad \mathrm{X} 9$ is (NIt - NI t-1) / (|Nit $|+|$ NIt-1 $\mid)$, which Nit is the current year's net income, and Nit-1 is the net profit one year before.

The logit function is considered suitable for modeling bankruptcy probabilities because the dependent variable has only two categories (bankrupt or not bankrupt). The logit function generates a probability result between 0 and 1 . If the calculation results are more than 0.38 , then the company has the opportunity to go bankrupt. Ohlson's model [6] provides an overall level of accuracy for estimation of samples of $96.6 \%$ and hold-out samples of $84 \%$ for a period of one year before bankruptcy.

\section{METHODS}

This research was conducted through three stages such as:

- Analyzing the accuracy of Z-Score to distinguish distress companies and solvent companies for the past 4 years using t-test and discriminant analysis.

- Analyzing the accuracy level of O-Score to distinguish distress companies and solvent companies for the past 3 years using t-test and discriminant analysis.

- Conducting interviews with related parties in the analysis, termination, and management of credit facilities regarding the granting criteria, applicable standard procedures and operations, financial report functions in credit analysis, and predictions of bankruptcy in credit management.

Data collection for research which is secondary data in the form of debtor financial data of the SME segment, was conducted through direct withdrawal from Bank Mandiri's internal credit scoring system.

Qualitative data collection was conducted through interviews with five bank employees in the Small Medium Enterprise segment's credit section, which were directly related to the credit process.

\section{RESULTS AND DISCUSSION}

Tests were conducted on hypotheses using the Altman four variables [7] and Ohlson O-Score formula [8]. The value of Z-Score and O-Score is obtained from the calculation of variables in the sample companies' financial statements.

These companies are classified as solvent companies and distress companies based on the companies' collectability recorded in Bank Mandiri data at the end of 2018, which was submitted to the Financial Services Authority. Companies with the collectability of one and two are categorized as solvent companies, while companies with the collectability of three, four, and five are categorized as distress companies.

For hypothesis 1 , the T-Test for equality of means is calculated at the 0.05 significance using the last four years' financial ratio. The study results are four, three, and two years before bankruptcy show that $\mathrm{HO}$ is accepted. It can be concluded that there is no significant difference between the Z-Score value of the solvent company and the value of the Z-Score Distress Company for that period. For one year before bankruptcy, the results show that $\mathrm{HO}$ is rejected and $\mathrm{Ha}$ 
is accepted. Therefore, it is concluded that there is a significant difference between the value of Z-Score of the solvent company and Z-Score Distress Company's value for that period. The discriminant analysis to view the classification accuracy at one, two, three, and four years before bankruptcy generates accuracy of $51.8 \%$, $37.4 \%, 36.3 \%$, and $11.4 \%$. This condition has a significant difference wherein the previous research using a four-variable Z-Score which can be used in various types of companies, provides an accuracy rate of up to $90.9 \%$ for one-year predictions before bankruptcy [7].

For the second hypothesis, the calculation is conducted with a significance of 0.05 using the sample company's last three years' financial ratio. The study results for three years before bankruptcy show that $\mathrm{H} 0$ is rejected and $\mathrm{Ha}$ is accepted. Therefore, it may be concluded that there is a significant difference between $\mathrm{O}$-Score's value from the solvent company and the value of Z-Score.Distress Company for that period. For the two and one-year period before bankruptcy, the study results show that $\mathrm{HO}$ is accepted and $\mathrm{Ha}$ is rejected. Therefore, it is concluded that there is no significant difference between the value of $\mathrm{O}$-Score from the company and the value of O-Score from the Distress Company for that period. The discriminant analysis shows the accuracy of classification at one, two, and three years before bankruptcy generates the results of accuracy of $73.6 \%, 43.2 \%$, and $58.5 \%$. This condition shows that the O-Score method has a significant level of accuracy in one year before bankruptcy, and this is in line with the previous research where the usage of the O-Score method generates an accuracy of up to $85 \%$ (hold out sample) for one-year predictions before bankruptcy [6].

There is a difference between the accuracy of the ZScore and O-Score methods applied in this research with the previous studies' accuracy. Accuracy for the ZScore and O-Score models obtained is lower than the previous research. To understand the causes of this occurrence, interviews were conducted with 5 Bank Mandiri employees who worked in the SME segment credit unit. Based on the interview results, it is noted that in processing the application of credit facilities, the majority of prospective debtors have been able to submit financial reports. Especially in Jakarta, approximately $30 \%$ of the debtors have financial reports audited by the Public Accountant Office, while the other $70 \%$ is in the form of in-house financial statements. However, for work units outside Jakarta, the composition of debtors/prospective debtors who have relatively low audited financial statements is approximately $5-10 \%$ of the total debtors.

\section{CONCLUSIONS}

The in-house financial statements submitted by prospective debtors do not fully reflect the company's real conditions and require field verifications. This happens due to the business operators in the SME segment have not fully understood the regulations for preparing financial statements. Therefore, errors are often found in preparing reports. For example, there is no proper separation between the company assets and the owner's assets, as well as the position of liabilities, where the company management records bank loans in the financial statements despite the fact that these debts are for the benefit of other parties, therefore, impacting the increasing total liabilities.

Based on the interview results, it is also concluded that in analyzing the provision of credit facilities in this segment, respondents assessed the character of the prospective debtors as the main consideration. This indicates that the company's personal figure in this segment is still very influential on future business prospects, including the potential bankruptcy which might be experienced.

\section{REFERENCES}

[1] Bank Indonesia and LPPI, Profil Bisnis Usaha Mikro, Kecil dan Menengah. Jakarta, 2015.

[2] N. Siddiqi, Intelligent credit scoring: Building and implementing better credit risk scorecards. 2016.

[3] S. A. Ross, "The arbitrage theory of capital asset pricing," 2013.

[4] S. A. Ross, D. J. Hillier, R. W. Westerfield, J. Jaffe, and B. D. Jordan, Corporate finance. McGraw Hill, 2010.

[5] E. I. Altman, B. Brady, A. Resti, and A. Sironi, "The link between default and recovery rates: Theory, empirical evidence, and implications," Journal of Business. 2005.

[6] J. A. Ohlson, "Financial ratios and the probabilistic prediction of bankruptcy," J. Account. Res., 1980.

[7] E. I. Altman, Corporate financial distress and bankruptcy: A complete guide to predicting \& avoiding distress and profiting from bankruptcy. 1993.

[8] J. A. Ohlson, "Price-earnings ratios and earnings capitalization under uncertainty," J. Account. Res., 1983. 